\title{
Prognosis Leukemia Limfoblastik Akut pada Anak Obes
}

\section{Teny Tjitra Sari, Endang Windiastuti, Gitta Reno Cempako, Yoga Devaera}

Departemen Ilmu Kesehatan Anak, RS Dr Cipto Mangunkusumo, Fakultas Kedokteran Universitas Indonesia, Jakarta

Latar belakang. Obesitas merupakan salah satu masalah gizi yang banyak ditemukan pada anak. Beberapa penelitian menunjukkan hubungan obesitas pada peningkatan risiko relatif beberapa keganasan. Keganasan yang paling sering ditemukan pada anak adalah leukemia limfoblastik akut. Bagaimana prognosis leukemia limfoblastik akut pada anak obes?

Tujuan. Mengetahui prognosis pasien leukemia limfoblastik akut anak dengan obesitas.

Metode. Studi deskriptif menggunakan data registrasi semua pasien baru leukemia limfoblastik akut pada 1 Januari 2007 - 31 Desember 2009 di Departemen Ilmu Kesehatan Anak FKUI/RSCM.

Hasil. Selama penelitian tiga tahun didapatkan 12 pasien leukemia limfoblastik akut dan obesitas dengan prevalens 6,1\%. Usia berkisar 2-14 tahun dengan rerata 6,4 tahun. Sembilan dari 12 pasien merupakan kelompok risiko tinggi dan sebagian besar ( 6 dari 9 pasien) datang dengan jumlah rerata leukosit adalah $101.650 / \mathrm{mm}^{3}\left(66.700-159.000 / \mathrm{mm}^{3}\right)$. Remisi pada fase induksi didapatkan pada 10 dari 12 pasien. Relaps terjadi pada tiga pasien, semuanya terjadi pada fase pemeliharaan dengan tempat relaps adalah sumsum tulang (dua pasien) dan intrakranial (satu pasien). Dua dari tiga subjek penelitian yang relaps, meninggal dunia dengan penyebab kematian perdarahan intrakranial.

Kesimpulan. Obesitas mempengaruhi prognosis pada pasien leukemia limfoblastik akut anak. (Sari Pediatri 2010;12(1):58-62).

Kata kunci: obesitas, leukemia limfoblastik akut

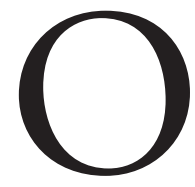

besitas merupakan salah satu masalah gizi yang banyak ditemukan di Indonesia. Prevalensi obesitas makin meningkat dan menjadi perhatian di seluruh dunia,

\section{Alamat korespondensi:}

Dr. Teny Tjitra Sari, Sp.A. Divisi Hematologi Onkologi Departemen Ilmu Kesehatan Anak FKUI- RSCM Jl. Salemba no. 6, Jakarta 10430. Telepon: 021-3907744, 31901170 Fax.021-3913982 baik pada orang dewasa maupun anak-anak. ${ }^{1}$ Di Amerika Serikat, obesitas ditemukan dengan prevalensi $10.4 \%$ pada usia $2-5$ tahun, $15,3 \%$ pada usia 6-11 tahun, dan $15,5 \%$ pada usia $12-19$ tahun. ${ }^{2}$ Obesitas meningkatkan risiko untuk menderita diabetes, penyakit kardiovaskular, penyakit respiratorik, infertilitas, dan kanker. ${ }^{3}$ Pasien yang menderita kanker dengan obesitas akan mempengaruhi insidens kanker dan juga pengobatannya. ${ }^{4-7}$ Sebuah studi meta-analisis terhadap 89 literatur telah mendapatkan hubungan 
berat badan lebih dan obesitas pada meningkatnya risiko relatif beberapa keganasan seperti kanker endometrium, payudara, dan ovarium. ${ }^{8}$ Hubungan patogenesis antara obesitas dengan kanker terletak pada peran adiposit dalam fungsi metabolik, sistem imun, dan fisiologi endokrin yang masing-masing berkontribusi terhadap proses karsinogenesis. Obesitas juga dihubungkan dengan peningkatan sitokin pro-inflamasi (seperti TNF- $\alpha$, acute phase reactant) dan adanya peran adiponektin dengan timbulnya kanker. ${ }^{9.10}$

Leukemia merupakan penyakit kanker yang terbanyak pada anak-anak. ${ }^{11}$ Leukemia limfoblastik akut (LLA) menempati peringkat paling atas diantara penyakit kanker anak yang dirawat di Departemen Ilmu Kesehatan Anak FKUI/RSCM dengan jumlah pasien baru 60-70 pasien per tahunnya. ${ }^{12}$ Hasil pengobatan leukemia sering dihubungkan dengan status gizi. Penelitian pada pasien leukemia mieloid akut anak dengan gizi kurang dan gizi lebih mempunyai survival lebih rendah dan treatment-related mortality yang lebih tinggi dibanding gizi baik. ${ }^{13}$

Tujuan penelitian untuk mengetahui prognosis pasien leukemia limfoblastik akut anak dengan obesitas.

\section{Metode}

Penelitian merupakan studi deskriptif menggunakan data registrasi yang melibatkan semua pasien baru leukemia limfoblastik akut pada 1 Januari 2007 31 Desember 2009 di Departemen Ilmu Kesehatan Anak FKUI/RSCM. Diagnosis leukemia limfoblastik akut ditegakkan melalui aspirasi sumsum tulang yang ditunjang dengan hasil Sudan Black negatif dan Periodic Acid Schiff positif. ${ }^{11}$ Pasien dikelompokkan sebagai risiko tinggi apabila ditemukan hiperleukositosis (nilai leukosit $>50.000 / \mathrm{mm}^{3}$ ), massa mediastinum, sel blast di likuor serebrospinalis, infiltrasi ke testis, LLA-L3, dan relaps. ${ }^{14}$

Obesitas ditegakkan bila didapatkan indeks massa tubuh (IMT) > persentil 95 sesuai dengan usia dan jenis kelamin saat diagnosis. Indeks massa tubuh dihitung dari berat badan (dalam kilogram) dibagi dengan tinggi badan (dalam meter) kuadrat. Kurva IMT yang digunakan adalah kurva CDC 2000. ${ }^{15}$

Analisis statistik dilakukan dengan menggunakan SPSS 11.5.

\section{Hasil}

Selama tahun 2007-2009 di Departemen Ilmu Kesehatan Anak FKUI/RSCM telah dirawat pasien baru leukemia limfoblastik akut 198 orang dengan 12 $(6,1 \%)$ diantaranya adalah pasien leukemia limfoblastik akut dengan obesitas.

Median follow-up penelitian 9,5 bulan (kisaran $1,0-18$ bulan). Usia rerata saat pertama kali diagnosis 6,4 tahun dengan kisaran antara 2-14 tahun. Hanya dua dari 12 subjek penelitian yang berusia $>10$ tahun dan keduanya mempunyai berat badan $>60$ kilogram. Perbandingan laki-laki dengan perempuan 3:1. Tabel 1 memperlihatkan karakteristik subjek penelitian.

Pada Tabel 1 terlihat bahwa jenis kelamin laki-laki lebih banyak dari perempuan. Kadar hemoglobin $<7$ $\mathrm{g} / \mathrm{dL}$, leukosit $<50.000 / \mathrm{mm}^{3}$ dan trombosit $<100.000 /$ $\mathrm{mm} 3$ merupakan hasil yang paling banyak ditemukan

Tabel 1. Karakteristik subjek $(\mathrm{n}=12)$

\begin{tabular}{|c|c|}
\hline Variabel & Jumlah \\
\hline \multicolumn{2}{|l|}{ Jenis kelamin } \\
\hline - Laki-laki & 9 \\
\hline - Perempuan & 3 \\
\hline \multicolumn{2}{|c|}{ Organomegali saat pertama kali diagnosis* } \\
\hline - Hepatomegali & 9 \\
\hline - Splenomegali & 7 \\
\hline \multicolumn{2}{|l|}{ Hemoglobin (g/dL) } \\
\hline$\bullet<7,0$ & 7 \\
\hline$\bullet>7,0$ & 5 \\
\hline \multicolumn{2}{|l|}{ Leukosit $\left(\right.$ x $\left.10.000 / \mathrm{mm}^{3}\right)$} \\
\hline$\bullet<50$ & 6 \\
\hline - $50-100$ & 3 \\
\hline$\bullet>100$ & 3 \\
\hline \multicolumn{2}{|l|}{ Trombosit $\left(/ \mathrm{mm}^{3}\right)$} \\
\hline$\bullet<100.000$ & 9 \\
\hline$\bullet>100.000$ & 3 \\
\hline \multicolumn{2}{|c|}{ Hasil aspirasi sumsum tulang } \\
\hline$\bullet$ LLA - L1 & 7 \\
\hline - LLA - L2 & 3 \\
\hline - LLA - L3 & 2 \\
\hline \multicolumn{2}{|l|}{ Jenis LLA } \\
\hline - Risiko biasa & 3 \\
\hline - Risiko tinggi & 9 \\
\hline - Hiperleukositosis & 6 \\
\hline - Massa mediastinum & 1 \\
\hline - LLA-L3 & 2 \\
\hline
\end{tabular}

* Dapat terjadi pada dua atau tiap pasien 
pada pemeriksaan penunjang. Hasil aspirasi sumsum tulang paling banyak menunjukkan LLA -L1. Subjek penelitian paling banyak dikelompokkan sebagai kelompok LLA dengan risiko tinggi.

Enam dari 9 subjek penelitian pada kelompok risiko tinggi disebabkan oleh hiperleukositosis dengan jumlah rerata leukosit adalah 101.650/ $\mathrm{mm}^{3}$ (66.700-159.000/ $\left.\mathrm{mm}^{3}\right)$. Sebagian besar subjek penelitian diterapi dengan menggunakan protokol LLA Indonesia. Subjek penelitian dengan kelompok risiko biasa diberikan protokol SR-A dan SR-B, sedangkan subjek kelompok risiko tinggi diberikan protokol HR-C dan protokol Jakarta yang dimodifikasi. Untuk pasien LLA-L3 diberikan protokol khusus.

Pada Gambar 1 terlihat bahwa yang mendapatkan terapi fase induksi hanya 11 subjek penelitian. First complete remission terjadi pada 10 subjek penelitian, sedangkan satu subjek menjalani remisi parsial. Subjek penelitian tersebut menderita Sindrom Down. Relaps kemudian terjadi pada tiga subjek penelitian yang semuanya terjadi pada fase pemeliharaan. Tempat relaps pada subjek tersebut adalah sumsum tulang (dua subjek) dan intrakranial (satu subjek). Dua dari 3 subjek penelitian yang relaps tersebut, akhirnya meninggal dunia dengan penyebab kematian perdarahan intrakranial. Sampai akhir penelitian, delapan subjek penelitian yang masih hidup. Terdapat

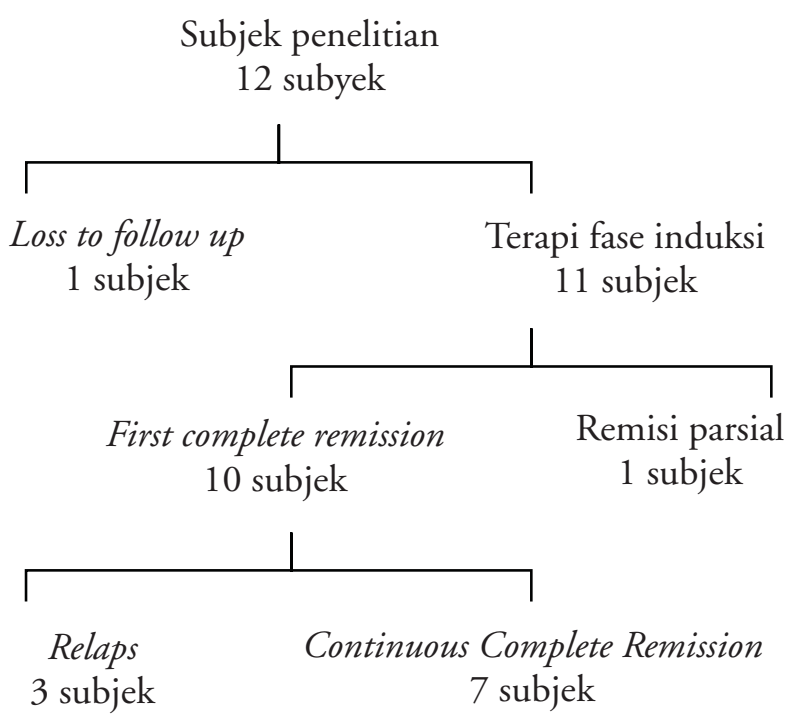

Gambar 1. Luaran pasien leukemia limfoblastik akut dengan obesitas satu dari dua subjek berusia lebih dari 10 tahun dengan berat badan lebih dari $60 \mathrm{~kg}$ yang relaps dan meninggal, sedangkan subjek lainnya tidak diketahui keadaannya (loss to follow up).

\section{Diskusi}

Leukemia merupakan kanker yang paling sering ditemukan pada anak. Laki-laki lebih sering ditemukan dibanding perempuan, sesuai dengan laporan oleh beberapa peneliti sebelumnya di negara-negara lain. ${ }^{16-}$ ${ }^{18}$ Jumlah pasien leukemia limfoblastik akut anak dengan obesitas di Departemen Ilmu Kesehatan Anak FKUI/RSCM adalah 6,1\%, hampir sama dengan yang didapatkan oleh Butturini $\mathrm{dkk}^{18}$ di Amerika Serikat $8 \%$.

Hiperleukositosis ditemukan pada 6 dari 12 pasien obesitas dengan kisaran leukosit 66.700-159.000/ $\mathrm{mms}^{3}$ (Tabel 2). Adanya tren jumlah leukosit tinggi lebih sering ditemukan pada pasien obesitas sesuai dengan adanya dampak obesitas terhadap pertumbuhan sel. ${ }^{18}$ Butturini $\mathrm{dkk}^{19}$ mendapatkan bahwa jumlah leukosit yang tinggi saat diagnosis juga merupakan salah satu prediktor outcome yang buruk pada pasien leukemia limfoblastik akut anak.

Hipotesis pada penelitian kami bahwa pasien obesitas mempunyai risiko tinggi untuk relaps karena dosis kemoterapi yang diterima tidak adekuat. Dosis ditentukan berdasarkan luas permukaan tubuh menjadi lebih kecil apabila dibandingkan dengan pasien non-obesitas. ${ }^{18,20}$ Obesitas pada anak usia 10 tahun atau lebih mempunyai risiko relaps 1,5 kali ( $\mathrm{p}=0,013)$ dibandingkan anak usia kurang dari 10 tahun. Jenis kelamin tidak mempunyai pengaruh terhadap kemungkinan relaps pada pasien leukemia limfoblastik anak remaja. Anak usia $>10$ tahun atau lebih dengan obesitas atau berat badan $>60 \mathrm{~kg}$ saat diagnosis mempunyai risiko tinggi untuk relaps dan event-free survival yang rendah. ${ }^{19}$ Pada penelitian kami hanya didapatkan 1 dari 2 pasien yang berusia $>10$ tahun dengan berat berat badan $>60 \mathrm{~kg}$, relaps pada fase pemeliharaan, namun kemudian meninggal karena perdarahan intrakranial.

Penelitian kami mendapatkan pasien obesitas yang mengalami relaps hingga tahun ketiga adalah 3 dari 12 pasien. Gatot dan Windiastuti tahun 2006 ${ }^{14}$ mendapatkan angka relaps pasien kelompok risiko tinggi $(18,5 \%)$ lebih besar dari pasien kelompok risiko biasa 
$(17,8 \%)$. Butturini $\mathrm{dkk}^{18}$ mendapatkan risiko relaps pada tahun ketiga pasien obesitas $30 \% \pm 4 \%$ dan non obesitas $20 \% \pm 1 \%(\mathrm{p}=0,01)$. Overall survival $\mathrm{pada}$ tahun ketiga untuk pasien obesitas adalah $68 \% \pm 5 \%$ dan non obesitas $80 \% \pm 1 \%(\mathrm{p}=0,008)$ sedangkan event-free survival tahun ketiga untuk pasien obesitas $63 \% \pm 5 \%$ dan non obesitas $74 \% \pm 1 \%$ yang bermakna secara statistik $(\mathrm{p}=0,01) \cdot{ }^{18} \mathrm{Hal}$ ini sebaliknya dengan yang ditemukan oleh Hijiya dkk. ${ }^{5}$ Pada penelitian tersebut mendapatkan bahwa tidak ada perbedaan yang bermakna overall survival, event-free survival, dan cumulative incidence of relapse pada tahun kelima antara pasien obesitas dan non-obesitas. Pada pasien obesitas didapatkan overall survival $78,2 \% \pm 5,5 \%$, event-free survival $72,7 \% \pm 5,9 \%$, dan cumulative incidencea of relapse $16,7 \% \pm 5,1 \% .{ }^{5}$ Sedangkan penelitian yang dilakukan oleh Butturini dkk ${ }^{19}$ mendapatkan overall survival pada tahun kelima untuk pasien obesitas adalah $61 \% \pm 3 \%$ dan non obesitas $74 \% \pm 1 \%(\mathrm{p}=0,008)$ sedangkan event-free survival tahun kelima untuk pasien obesitas $57 \% \pm 15 \%$ dan non obesitas $67 \% \pm 1 \%$ yang bermakna secara statistik $(\mathrm{p}=0,01)$. Risiko relaps pada tahun kelima pasien obesitas $40 \% \pm 5 \%$ dan non obesitas $29 \% \pm 1 \%(\mathrm{p}=0,01) .{ }^{19}$ Semua penelitian tersebut, memperlihatkan bahwa pasien obesitas mempunyai risiko relaps lebih tinggi dibanding pasien non-obesitas. Perbedaan hasil penelitian kami dengan penelitian sebelumnya disebabkan oleh jumlah subjek penelitian yang sangat sedikit. Hal ini juga merupakan kelemahan penelitian ini dibanding penelitian sebelumnya., ${ }^{5,18}$

Osteonekrosis dikenal sebagai komplikasi akibat terapi pada pasien leukemia limfoblastik akut. ${ }^{21}$ Penelitian Niimäki dkk ${ }^{21}$ di Finlandia mendapatkan bahwa indeks massa tubuh (IMT) yang tinggi merupakan faktor risiko untuk terjadinya osteonekrosis pada pasien leukemia limfoblastik akut anak yaitu rasio Odds 7,538 (IK 95\%: 1,918 sampai 29,627, p=0,004). Sebaliknya Hijiya $\mathrm{dkk}^{5}$ mendapatkan tidak ada perbedaan terjadinya toksisitas akibat kemoterapi pada pasien obesitas dan non-obesitas yang bermakna secara statistik. Salah satu kelemahan lain dari penelitian ini adalah tidak ada data yang lengkap mengenai toksisitas yang terjadi.

Studi farmakokinetik pada obesitas menunjukkan bahwa molekul yang mempunyai sifat lipofilik ringan atau sedang secara umum lebih mudah diprediksi karena obat tersebut didistribusikan terutama pada massa otot. Dengan demikian, dosis obat tersebut harus berdasarkan berat badan ideal. Pada beberapa obat-obatan seperti obat kanker, hanya sebagian didistribusikan di jaringan lemak, dosis obat ditentukan berdasarkan IMT ditambah persentase kelebihan berat badan. ${ }^{6}$ Penelitian terhadap pasien leukemia limfoblastik akut anak memperlihatkan bahwa terdapat penurunan rerata dosis relatif L-asparginase sebesar 7\% pada pasien obesitas dibanding pasien non-obesitas. Perbedaan dosis ini lebih besar pada pasien usia 10-18 tahun dibanding usia 2-9 tahun. Hal ini mungkin disebabkan oleh tingginya IMT pada anak usia 10-18 tahun sehingga modifikasi dosis menjadi lebih besar. ${ }^{7}$

Obesitas meningkatkan risiko untuk menderita kanker. Beberapa mekanisme yang dianggap berperan adalah meningkatnya hormon endogen (hormon sex steroids, insulin dan insulin growth fasctore-1) karena adanya akumulasi lemak tubuh yang berperan penting dalam mengontrol pertumbuhan, diferensiasi dan metabolisme sel. Inflamasi kronik juga berperan dalam timbulnya sel kanker. Sel adiposit merupakan sumber poten untuk timbulnya sitokin inflamasi. Respons inflamasi sistemik ini ditandai dengan meningkatnya konsentrasi $C$-reactive protein yang berhubungan dengan timbulnya kanker. Obesitas juga meningkatkan stres oksidatif melalui proses inflamasi dan meningkatnya kerusakan oksidatif pada DNA sehingga dapat meningkatkan risiko kanker pada obesitas. ${ }^{4}$ Virchow (1863) adalah ilmuwan yang pertama kali menghubungkan inflamasi kronik dengan kanker. ${ }^{10}$ Penelitian Barb $\mathrm{dkk}^{10}$ menghubungkan peran adiponektin dengan kanker. Adiponektin yaitu suatu protein yang disekresikan oleh adiposit dan berperan penting dalam pengaturan sensitifitas insulin dan inflamasi, dengan kanker. ${ }^{10,22}$ Berkurangnya kadar adiponektin berhubungan erat dengan peningkatan jenis kanker tertentu. Namun belum terbukti adanya keterkaitan yang bermakna antara penurunan kadar protein ini dengan peningkatan leukemia pada anak. ${ }^{10}$

Sebagai kesimpulan, obesitas mempengaruhi terapi pada leukemia limfoblastik akut, dengan demikian obesitas juga mempengaruhi outcome pada leukemia limfoblastik akut anak.

\section{Daftar Pustaka}

1. Hedley AA, Ogden CL, Johnson CL, Carroll MD, Curtin LR, Flegal KM. Prevalence of overweight and obesity among US children, adolescents, and adults, 1999-2002. JAMA 2004;291:2847-50. 
Teny Tjitra Sari dkk: Prognosis leukemia limfoblastik akut pada anak obes

2. Ogden CL, Flegal KM, Carroll MD. Prevalence and ws trends in overweight among US children and adolescents, 1999 - 2000. JAMA 2002;288:1728-32.

3. Donohoue PA. Obesity. Dalam: Behrman RE, Kliegman RM, Jenson HB, penwsyunting. Nelson Textbook of Pediatrics. Edisi ke-17. Philadelphia: WB Saunders;2003. h.108.

4. McMillan DC, Sattar N, Lean M, McArdle CS. Obesity and cancer. BMJ 2006;333:1109-11

5. Hijiya N, Panetta JC, Zhou Y, Kyzer EP, Howard SC, Jeha S, dkk. Body mass index does not influence pharmacokinetics or outcome of treatment in children with acute lymphoblastic leukemia. Blood 2006;108:3997-4002.

6. Cheymol G. Effects of obesity on pharmacokinetics implications for drug therapysw. Clin Pharmacokinet 2000;39:215-31.

7. Baillargeon J, Langevin AM, Lewis $M$, Thomas PJ, Mullins J, Dugan J, dkk. L-Asparaginase as a marker of chemotherapy dose modification in children with acute lymphoblastic leukemia. Cancer 2005;104:2858-61.

8. Guh DP, Zhang W, Bansback N, Amarsi Z, Birmingham $\mathrm{CL}$, Anis AH. The incidence of co-morbidities related to obesity and overweight:A systematic review and metaanalysis. BMC Public Health 2009;9:88.

9. Hong K, Yan E, Chen S, Li Z, Heber D. Obesity and Cancer: Inflammation and Molecular Pathogenesis. Obesity Manag 2007;3:115-20.

10. Barb D, Williams CJ, Neuwirth AK, Mantzoros CS. Adiponectin in relation to malignancies: a review of existing basic research and clinic swal evidence. Am J Clin Nutr 2007;86:858S-66S.

11. Lanzkowsky P. Manual of pediatric hematology and oncology. Edisi ke-4. Burlington: Elsevier Academic Press; 2005.h.415-52.

12. Data registrasi kanker. Divisi Hematologi Onkologi FKUI/RSCM 2009.

13. Lange BJ, Gerbing RB, Feusner J, Skolnik J, Sacks $\mathrm{N}$, Smith FO, dkk. Mortality in overweight and undesrweight chilsdren with acute myeloid leukemia. JAMA 2005 12;293:203-11.

14. Gatot D, Windiastuti E. Treatment of childhood acute lymphoblastic leukemia in Jakarta: Result of modified Indonesian National Protocol 94. Paediatr Indones 2006;46:179-84

15. CDC Growth Charts. Diunduh dari: www.cdc.gov/ growthcharts/clinical_charts.htm. Tanggal 15 Desember 2009.

16. Li J, Thompson TD, Miller JW, Pollack LA, Stewart SL. Cancer incidence among children and adolescents in the United States, 2001-2003. Pediatrics 2008;121:e1470-7.

17. Mejía-Aranguré JM, Bonilla $M$, Juárez-Ocaña $S$, de Reyes G, Pérez-Saldivar ML, González-Miranda G, dkk. Incidence of leukemias in children from El Salvador and Mexico City between 1996 and 2000:Population-based data. BMC Cancer 2005;5:33.

18. Butturini AM, Dorey FJ, Lange BJ, Henry DW, Gaynon PS, Fu C, dkk. Obesity and outcome in pediatric acute lymphoblastic leukemia. J Clin Oncol 2007;25:2063-9.

19. Butturini A, Dorey F, Gaynon P, Fu C, Franklin J, Siegel S, dkk. Obesity and body weight independently predict relapse and survival in preadolescents and teenagers with acute lymphoblastic leukemia (ALL): A retrospective analysis of five Children Cancer Group (CCG) studies. Blood (ASH Annual Meeting Abstracts) 2004;104:Abstract 992.

20. Rogers CP, Meacham LR, Oeffinger KsC, Henry DW, Lange BJ. Review: Obesity in pediatric oncology. Pediatr. Blood Cancer 2005; 45:881-9.

21. Niinimäki RA, Harila-Saari AH, Jartti AE, Seuri RM, Riikonen PV, Pa“a"kkö EL, dkk. High body mass index increases the risk for osteonecrosis in children with acute lymphoblastic leukemia. J Clin Oncol 2007;25:1498504.

22. Kelesidis I, Kelesidis T, Mantzoros CS. Adiponectin and cancer: a systematic review. British Journal of Cancer 2006;94:1221-5. 